\title{
O POTRZEBIE ISTNIENIA SUROWOŚCI KARY JAKO SAMOISTNEJ PRZESŁANKI STOSOWANIA TYMCZASOWEGO ARESZTOWANIA. ROZWAŻANIA I WNIOSKI NA TLE WYKŁADNI ART. 258 § 2 K.P.K.
}

\section{WSTĘP}

Zagrożenie ustawowe zarzucanego oskarżonemu przestępstwa stanowi jedna ze szczególnych podstaw stosowania tymczasowego aresztowania określonych w art. 258 k.p.k. ${ }^{1}$, spośród których zaistnieć musi co najmniej jedna, aby możliwe było stosowanie jakichkolwiek środków zapobiegawczych. Zgodnie z art. $258 \S 2$ k.p.k., jeżeli oskarżonemu zarzuca się popełnienie zbrodni lub występku zagrożonego kara pozbawienia wolności, której górna granica wynosi co najmniej 8 lat, albo gdy sąd pierwszej instancji skazał go na kare pozbawienia wolności nie niższą niż 3 lata, potrzeba zastosowania tymczasowego aresztowania $\mathrm{w}$ celu zabezpieczenia prawidłowego toku postępowania może być uzasadniona grożąca oskarżonemu surowa kara. W ocenie autora nie można podzielić podnoszonych przez część przedstawicieli doktryny procesu karnego wątpliwości dotyczących tego przepisu, ponieważ nie zakłada on automatyzmu stosowania tymczasowego aresztowania w razie spełnienia przesłanek, o których w nim mowa, albowiem regulacja ta ma charakter fakultatywny i uzupełniajaccy w stosunku do pozostałych podstaw stosowania środków zapobiegawczych, o których mowa w art. 258 § 1 i 3 k.p.k. Nie jest zatem uzasadniona krytyka dotycząca nieproporcjonalności tej podstawy w stosunku do skutków, jakie niesie ze sobą tymczasowe aresztowanie. Zagadnienie to ma na powrót zasadnicze znaczenie z uwagi na dużą liczbę kierowanych przeciwko Polsce skarg do Europejskiego Trybunału Praw Człowieka (ETPC) związanych ze stosowaniem tymczasowego aresztowania, jak również z uwagi na zasygnalizowana przez Trybunał Konstytucyjny (TK) potrzebę zmiany przepisów w tym zakresie.

\footnotetext{
${ }^{1}$ Ustawa z 6 czerwca 1997 r. - Kodeks postępowania karnego, Dz. U. 1997, Nr 89, poz. 555 ze zm. (dalej jako: k.p.k.).
} 


\section{HISTORIA REGULACJI}

Surowość zagrożenia ustawowego przestępstwa zarzucanego oskarżonemu jako podstawa aresztowa nie jest instytucją nową i choć kilkukrotnie nowelizowana, obecna była już w pierwotnej wersji Kodeksu postępowania karnego. Co więcej, obecne brzmienie przepisu art. 258 § 2 k.p.k. jest dosłownym powtórzeniem pierwotnej jego wersji z 1997 r. ${ }^{2}$ Już także przedwojenny Kodeks postępowania karnego ${ }^{3} \mathrm{w}$ art. 165 lit. b przewidywał, że tymczasowe aresztowanie może nastapić tylko wtedy, gdy „sprawa toczy się o przestępstwo, za które ustawa przepisuje karę pozbawienia wolności do jednego roku lub karę cięższa, a zachodzi uzasadniona obawa, że oskarżony będzie nakłaniał świadków do fałszywych zeznań lub w inny sposób starał się o usunięcie dowodów przestępstwa".

Regulacja ta, podobnie jak współczesna, posługiwała się zagrożeniem ustawowym przestępstwa jako jednym $\mathrm{z}$ warunków stosowania tymczasowego aresztowania, jednakże - co istotnie odróżnia ją od obecnej regulacji wymagała dodatkowo spełnienia jednego z dwóch warunków pozostających $\mathrm{w}$ koniunkcji z zagrożeniem ustawowym danego czynu, a mianowicie obawa matactwa lub zatarcia dowodów. De lege lata bowiem uzasadniona obawa matactwa lub innego bezprawnego utrudniania postępowania (obok uzasadnionej obawy ucieczki) stanowi odrębną niezależną od zagrożenia ustawowego czynu podstawę do zastosowania środków zapobiegawczych (art. 258 § 1 pkt 2 k.p.k.). Dodać należy, że k.p.k. z 1928 r. przewidywał także inną zbliżoną do omawianego zagadnienia podstawę aresztowa, a mianowicie: „gdy oskarżony jest przestępca nałogowym, zawodowym lub recydywistą". Naturalną konsekwencją powyższego było przewidywanie, że oskarżonemu wymierzona zostanie surowsza kara, co zbliża tę regulację do omawianego zagadnienia, mimo iż obowiąujący Kodeks nie przewiduje explicite takiej podstawy stosowania środków zapobiegawczych. Warto nadmienić, iż przedwojenny k.p.k. w zakresie kryterium zagrożenia ustawowego czynu przewidywał stanowczo niższy próg ustawowego zagrożenia przestępstwa, ponieważ wystarczające było zagrożenie danego czynu karą pozbawienia wolności do 1 roku lub cięższa.

Kodeks karny z 1932 r. $^{4}$ posługiwał się jednak innymi terminami i w katalogu kar przewidywał karę śmierci, więzienie (od 6 miesięcy do 15 lat lub dożywocie), areszt (od tygodnia do 5 lat) i grzywnę. Rozbieżność ta ma charakter wyłącznie terminologiczny, przez co rozumieć należy to, iż k.p.k. odwoływał się do kary więzienia, która w przeciwieństwie do aresztu miała charakter izolacyjny. Inaczej zatem niż teraz, ówczesny kodeks przewidywał wyłącznie górna granicę zagrożenia zarzucanego oskarżonemu czynu, która musiała wy-

\footnotetext{
${ }^{2}$ Pierwotny tekst k.p.k. zob.: Dz. U. 1997, Nr 89, poz. 555.

${ }^{3}$ Rozporządzenie Prezydenta Rzeczypospolitej z 19 marca 1928 r. Kodeks postępowania karnego, Dz. U. Nr 33, poz. 313.

${ }^{4}$ Rozporządzenie Prezydenta Rzeczypospolitej z 11 lipca 1932 r. - Kodeks karny, Dz. U. Nr 60, poz. 571.
} 
nosić minimum 1 rok. W przypadku przestępstw zagrożonych karą poniżej roku tymczasowe aresztowanie było niedopuszczalne na tej podstawie ${ }^{5}$.

Zasadniczą zmianę w pojmowaniu rodzaju i charakteru przestępstwa dla stosowania środków zapobiegawczych przyniósł k.p.k. z 1969 r. ${ }^{6}$, który pierwotnie przewidywał dwie niezależne od siebie podstawy tymczasowego aresztowania, a mianowicie jeżeli oskarżonemu zarzucono zbrodnię lub działanie w warunkach powrotu do przestępstwa określonych w kodeksie karnym (art. 217 § 1 pkt 3 k.p.k.) lub oskarżonemu zarzucono czyn, którego stopień społecznego niebezpieczeństwa jest znaczny (art. 217 § 1 pkt 4 k.p.k.). Na mocy jednak noweli tego Kodeksu z 1995 r. ${ }^{7}$ podstawy tymczasowego aresztowania zostały określone w sposób analogiczny jak w k.p.k. z 1997 r. O ile w przypadku pierwszej z wymienionych podstaw tymczasowego aresztowania jej przesłanki wyinterpretować można było wprost z norm karnomaterialnych, o tyle w przypadku drugiej podstawy była ona wyjątkowo nieostra i ocenna, w związku z czym też podstawa ta była w znacznym stopniu nadużywana przez organy procesowe, albowiem właśnie na nią najczęściej się powoływano ${ }^{8}$. Nie budzi jednak żadnych wątpliwości, iż brzmienie art. $217 \S 1$ pkt 3 i 4 k.p.k. określało każdą z tych przesłanek jako niezależną od pozostałych podstawę do stosowania tego izolacyjnego środka zapobiegawczego. Wyraz temu dał Sąd Apelacyjny w Krakowie, który stwierdził, że: „W obecnym stanie prawnym [w 1994 r. - przy. J.K.] nie można odmówić racji poglądowi, że znaczny stopień społecznego niebezpieczeństwa czynu może być przesłanką samodzielnie uzasadniajaca stosowanie tymczasowego aresztowania sprawcy (art. $217 \S 1$ pkt 4 k.p.k.)"

Z kolei w kontekście k.p.k. z 1997 r. wyrażano wątpliwość, „czy dla zastosowania tymczasowego aresztowania, w sytuacji gdy nie orzeczono jeszcze kary, wystarczające jest tylko zagrożenie karne określone w tym przepisie, czy też istotny jest przewidywany wymiar kary"10. Nie przesądzając w tym miejscu tej kwestii, wskazywano, że: „Końcowa treść art. $258 \S 2$ przesądza o tym, że ma to być przewidywana kara, jaka zostanie wymierzona oskarżonemu"11.

W obecnym kształcie przepis art. 258 § 2 k.p.k. funkcjonował do 1 lipca 2015 r., tj. do czasu wejścia w życie nowelizacji z 2013 r. ${ }^{12}$. Już jednak nowela z 2016 r. ${ }^{13}$ na powrót przywróciła wcześniejsze brzmienie przepisu, a co za

5 Peiper (1932): 208; zob. też Różycki (1933): 135-136.

${ }^{6}$ Ustawa z 19 kwietnia 1969 r. Kodeks postępowania karnego, Dz. U. Nr 13 poz. 96.

7 Ustawa z 29 czerwca 1995 r. o zmianie Kodeksu postępowania karnego, ustawy o ustroju sądów wojskowych, ustawy o opłatach w sprawach karnych i ustawy o postępowaniu w sprawach nieletnich, Dz. U. Nr 89, poz. 443.

8 Murzynowski (1997a): 12.

9 Postanowienie SA w Krakowie z 29 czerwca 1994 r., II AKz 242/94, Lex nr 28214; zob. też: Murzynowski (1997b): 140.

10 Stefański (1998): komentarz do art. 258, teza nr 7.

11 Stefański (1998).

12 Ustawa z 27 września 2013 r. o zmianie ustawy - Kodeks postępowania karnego oraz niektórych innych ustaw, Dz. U. poz. 1247.

13 Ustawa z 11 marca 2016 r. o zmianie ustawy - Kodeks postępowania karnego oraz niektórych innych ustaw, Dz. U. poz. 437. 
tym idzie, zachowują aktualność poglądy wyrażone na tle wcześniejszego jego brzmienia. De lege lata przewidziana w art. 258 § 2 k.p.k. podstawa tymczasowego aresztowania stanowić może samoistna przesłankę dla jego zastosowania niezależnie od spełnienia pozostałych przesłanek, o jakich mowa w $\S 1$ i 3 tego artykułu, co wynika explicite z brzmienia tego przepisu. W jego części in fine ustawodawca stanowi, że ,potrzeba zastosowania tymczasowego aresztowania w celu zabezpieczenia prawidłowego toku postępowania może być uzasadniona grożąca oskarżonemu surową karą". W krótkim okresie obowiązywania reformy zwiększającej kontradyktoryjność procesu karnego przesłanka ta z kolei miała charakter niesamodzielny, na co wskazywało wprost użyte w nim sformułowanie, że „obawy utrudniania prawidłowego toku postępowania, o których mowa w $\S 1$, uzasadniające stosowanie środka zapobiegawczego, mogą wynikać także z surowości grożącej oskarżonemu kary”.

Powyższe widoczne było wyraźnie w ewoluujacym na gruncie tych zmian orzecznictwie sądów powszechnych. Ugruntowane jest stanowisko, że: „Zgodnie z poglądem dominujacym w orzecznictwie, przesłanka szczególna z art. 258 $\S 2$ k.p.k. może stanowić samodzielna podstawę stosowania izolacyjnego środka zapobiegawczego. Podkreśla się przy tym, że to nie sama możliwość skazania na surową karę uzasadnia tymczasowe aresztowanie oskarżonego, ale wynikająca stąd obawa, że przewidując, iż zostanie mu wymierzona taka kara, oskarżony może podjąć działania w celu zdestabilizowania prawidłowego toku postępowania. Temu zapobiec może wyłącznie stosowanie tymczasowego aresztowania"14. Na podobnym stanowisku staje Ewa Grzęda, wskazując, że: „Samo odwołanie się do abstrakcyjnego maksimum grożącej kary przewidzianej przez ustawodawcę nie może stanowić podstawy do orzeczenia tymczasowego aresztowania z powodów aksjologicznych i wykładniczych"15. Samodzielność art. 258 § 2 k.p.k. wyraża się w tym, że w każdym przypadku konieczne jest wskazanie in concreto okoliczności uzasadniających wysoki stopień prawdopodobieństwa, że oskarżonemu wymierzona zostanie surowa kara.

Jako nieaktualny i mniejszościowy pogląd dla porządku wskazać należy na inne postanowienie Sądu Apelacyjnego w Krakowie, w myśl którego: „Przywrócenie ustawą nowelizująca z 2016 roku brzmienia art. 258 § 2 k.p.k. sprzed dnia wejścia w życie ustawy nowelizującej z 2013 roku, to jest sprzed 1 lipca 2015 roku, nie uprawnia do samodzielnego powoływania art. 258 § 2 k.p.k. jako podstawy stosowania bądź przedłużania tymczasowego aresztowania"16. Niesamodzielność tej przesłanki miała bowiem miejsce jedynie w odniesieniu do reformy z 2013 r., na co wskazuje postanowienie Sądu Apelacyjnego w Katowicach, który słusznie stwierdził, że „brzmienie art. 258 § 2 k.p.k., zmienione nowelizacją z 27 września 2013 r. poprzez dodanie słowa »także« wskazuje, że owe obawy utrudniania przez oskarżonego prawidłowego toku postępowania, czy to ucieczki lub ukrycia się oskarżonego, czy też matactwa z jego strony bądź innego bezprawnego utrudniania procesu, nie mogą wynikać wyłącznie

\footnotetext{
14 Postanowienie SA w Krakowie z 11 października 2017 r., II AKz 389/17, Lex nr 2536076/

15 Grzęda (2015): 143.

16 Postanowienie SA w Krakowie z 5 maja 2016 r., II AKz 151/16, Lex nr 2031143.
} 
z surowości grożącej kary pozbawienia wolności, lecz powinny znajdować oparcie w ustaleniach wskazujących na ich istnienie" ${ }^{\prime 17}$.

W doktrynie również brak spójności co do pojmowania samodzielności tej przesłanki. Część autorów wskazywała na to, że przepis art. 258 § 2 k.p.k. „nie jest wystarczająca przesłanką do stosowania tymczasowego aresztowania [...], a jedynie pozwala na przyjęcie domniemania, że w tym wypadku tymczasowe aresztowanie jest niezbędne w celu zabezpieczenia prawidłowego toku postępowania, co powinno być jednak wykazane w uzasadnieniu odpowiedniego postanowienia"18. Oczywiste jest jednak, że postawienie oskarżonemu zarzutu występku, którego górna granica zagrożenia wynosi 8 lat, nie pociaga za soba automatycznie przymusu stosowania tymczasowego aresztowania, albowiem konieczne jest zbadanie okoliczności sprawy, które muszą uzasadniać prawdopodobieństwo wymierzenia surowej kary, lecz niezależnie od spełnienia przesłanek z art. 258 § 1 k.p.k. Krzysztof Dabkiewicz wskazuje, że „stosowanie tymczasowego aresztowania na podstawie tego przepisu [art. $258 \S 2$ k.p.k. J.K.] nie może być bowiem antycypacją grożącej oskarżonemu (podejrzanemu) surowej kary"19.

W doktrynie przyjęło się, iż groźba surowej kary musi być realna, a przez pojęcie surowości kary przyjęło się rozumieć karę w wymiarze przekraczającym 3 lata pozbawienia wolności ${ }^{20}$. O grożącej oskarżonemu surowej karze powinny rozstrzygać okoliczności sprawy oraz dane osobopoznawcze oskarżanego $^{21}$. Jednoznacznie powyższą kwestię, na wniosek Rzecznika Praw Obywatelskich, rozwiązał Sąd Najwyższy, wskazując bez wątpliwości, że ,podstawy stosowania tymczasowego aresztowania, określone w art. $258 \S 2$ k.p.k., przy spełnieniu przesłanek wskazanych w art. $249 \S 1$ i art. $257 \S 1$ k.p.k. i przy braku przesłanek negatywnych określonych w art. $259 \S 1$ i 2 k.p.k., stanowią samodzielne przesłanki szczególne stosowania tego środka zapobiegawczego" 22 .

\section{KONTROLA KONSTYTUCYJNOŚCI PRZEPISU}

Powyższe przesądzenie samodzielności przesłanki z art. $258 \S 2$ k.p.k. dla możliwości stosowania tymczasowego aresztowania nie rozwiązało jednak wszystkich wątpliwości związanych z funkcjonowaniem tej normy w obszarze procesu karnego. Już przy okazji, określanej mianem wielkiej, nowelizacji k.p.k. z 2013 r. Barbara Nita i Andrzej Światłowski wskazywali, że: „W świetle art. 31 ust. 3 Konstytucji, surowością grożącej i wymierzonej kary nie można usprawiedliwiać ingerencji w konstytucyjnie gwarantowane prawa osoby, któ-

\footnotetext{
17 Postanowienie SA w Katowicach z 2 grudnia 2015 r., II AKz 687/15, Lex nr 2023129.

18 Hofmański (2011): 1446.

19 Dąbkiewicz (2012): 117.

20 Eichstaedt (2018): 958.

21 Eichstaedt (2016): 252.

22 Uchwała SN z 19 stycznia 2012 r., I KZP 18/11, Lex nr 1102081.
} 
rej ma dotyczyć tymczasowe aresztowanie"23. Autorzy ci pozytywnie odnosza się do (projektowanej wówczas) zmiany art. $258 \S 2$ k.p.k. na podstawie nowelizacji z 2013 r., nie wskazując jednak kryteriów uzasadniających tę krytykę.

Badając problem konstytucyjności określonej w art. 258 § 2 k.p.k. przesłanki tymczasowego aresztowania, nie można tracić z pola widzenia celów, jakie ma spełniać ten środek zapobiegawczy. Z art. 249 § 1 k.p.k. wynika, że środki zapobiegawcze mają pełnić głównie funkcje prewencyjną i zapewnić prawidłowy tok postępowania, niemniej pełnią one również funkcję ochronną polegająca na zapobieżeniu popełnienia przez oskarżonego nowego przestępstwa, co najpełniej realizuje tymczasowe aresztowanie ${ }^{24}$. Tymczasowe aresztowanie, jako środek polegający na pozbawieniu wolności, spełniać musi szczególne kryteria wywodzące się z konstytucyjnej ochrony prawa do wolności, na co zwraca uwagę Jerzy Skorupka, wskazując, że: „Ustawowa regulacja tymczasowego aresztowania musi więc służyć ochronie interesu publicznego, odnoszącego się do jednej z sześciu sfer szczególnych wskazanych w art. 31 ust. 3 Konstytucji. Brak takiego materialnego powiązania przesądza o braku konstytucyjnej podstawy do ustanowienia ograniczeń" ${ }^{25}$. Jednocześnie autor ten wskazuje, że „Mając na względzie cel tymczasowego aresztowania, którym jest zabezpieczenie prawidłowego toku postępowania karnego, a także zapobiegnięcie popełnieniu przez oskarżonego nowego, ciężkiego przestępstwa, można stwierdzić, że pozbawienie wolności z powodu zastosowania tego środka następuje dla ochrony jednej z wartości wymienionych w art. 31 ust. 3 Konstytucji, w szczególności dla ochrony bezpieczeństwa i porządku publicznego oraz wolności i praw innych osób" ${ }^{26}$. Powyższa konstatacja stanowić musi podstawę do dokonywania ocen w zakresie potrzeby istnienia regulacji przewidzianej w art. $258 \S 2$ k.p.k. oraz jej zgodności z zasadą proporcjonalności i ochroną wolności wynikających z Konstytucji.

Radosław Koper zauważa, że: „Z jednej strony, przez swoją nieprecyzyjność daje sądowi zbyt dużą swobodę w zakresie podejmowania decyzji o zastosowaniu lub przedłużeniu tymczasowego aresztowania. Może to prowadzić do sytuacji, w której ingerencja w zakres wolności, przybierajaca postać najsurowszego środka zapobiegawczego, niekoniecznie będzie niezbędnym i jedynym sposobem rozwiązania występującej kolizji wartości - z powodu braku możliwości ściślejszego skonkretyzowania zagrożenia dla celów procesu, a w rezultacie uciążliwość wynikająca z tego tytułu dla jednostki nie będzie pozostawać w odpowiedniej proporcji do założonego celu wiążącego się z zagrożeniem karą. Z drugiej strony, jeżeli wskazany cel uzyskuje charakter nadrzędny, omawiany przepis godzi w konstytucyjna zasadę domniemania niewinności oskarżonego" ${ }^{27}$. Trzeba jednak wskazać, że takie samo stanowisko można wyrazić co do pozostałych przesłanek stosowania tymczasowego aresztowania, a to z tego powodu, że powyższy zarzut względem art. $258 \S 2$

\footnotetext{
23 Nita, Światłowski (2013): 92.

${ }^{24}$ Hofmański, Waltoś (2016): 432-433.

25 Skorupka (2012): 56.

26 Skorupka (2012): 61.

27 Koper (2013): 6.
} 
k.p.k. ma charakter generalny. Co więcej, wydaje się wręcz, że przesłanka $\mathrm{z}$ art. $258 \S 2$ k.p.k. jest bardziej skonkretyzowana aniżeli obawa matactwa czy bezprawnego utrudniania postępowania, szczególnie, iż utarta linia orzecznicza jednoznacznie wskazuje, że zaistnienie tych przesłanek nie musi wiązać się z podjęciem przez oskarżonego czynności, o jakich mowa w art. $258 \S 1$ pkt 1 i 2 k.p.k. Wszak tymczasowe aresztowanie ma właśnie chronić przed nimi. Wydaje się zatem, że zarzut ten nie jest trafiony. Ten sam zreszta autor wskazuje, że: „Błędem byłoby jednak założenie postulujące zupełne wykreślenie z k.p.k. podstawy tymczasowego aresztowania opierającej się na wysokości grożącej lub wymierzonej surowej kary. Względy społeczne przemawiają za utrzymaniem tego rodzaju przepisu w polskim porządku karnoprocesowym" ${ }^{28}$.

\section{Stanowisko Trybunału Konstytucyjnego}

$\mathrm{Z}$ punktu widzenia omawianego zagadnienia nie można tracić tego, że przepisy k.p.k. dotyczące tymczasowego aresztowania, $\mathrm{w}$ tym również przepis art. $258 \S 2$ k.p.k., zostały poddane kontroli zgodności z Konstytucja. Trybunał Konstytucyjny w niedawnym wyroku z 10 lipca 2019 r. $^{29}$, po rozpoznaniu wniosku Rzecznika Praw Obywatelskich z 8 stycznia 2016 r. ${ }^{30}$ m.in. o zbadanie zgodności z Konstytucją RP art. $258 \S 2$ k.p.k., wyrokiem co prawda umorzył postępowanie w tym zakresie ze względu na zmianę stanu prawnego, jednakże wskazał, że „w porównaniu z wcześniejszym stanem prawnym [przed 1 lipca 2015 r. i obecnie funkcjonujaccym - J.K.] istotnie zmniejszono w nim znaczenie surowości grożącej oskarżonemu kary jako czynnika miarodajnego dla orzekania tymczasowego aresztowania. Do 30 czerwca 2015 r. sąd mógł zastosować ten środek zabezpieczający stosunkowo łatwo, bo bez konieczności wykazania, w jaki sposób grożąca danemu oskarżonemu kara w konkretny sposób utrudni postępowanie, tzn. czy zwiększa ryzyko ucieczki lub ukrywania się oskarżonego, wpływania przez niego na świadków lub współoskarżonych, niszczenia dowodów itd.”. Trybunał uznał, że wobec złożenia wniosku Rzecznika Praw Obywatelskich na gruncie brzmienia k.p.k. nadanego mu na mocy noweli z 2013 r. i zmiany przepisu art. 258 § 2 k.p.k. zgodnie z nowela z 2016 r. nie jest on kompetentny do zbadania zgodności z Konstytucją nowego brzmienia tego przepisu, który jest tożsamy z brzmieniem sprzed 1 lipca 2015 r.

Jednocześnie jednak nie sposób nie zauważyć, że TK wyraźnie aprobująco odniósł się do powiązania art. $258 \S 2$ k.p.k. z pozostałymi przesłankami tymczasowego aresztowania z $\S 1$ tego artykułu, z czego jednak ustawodawca na powrót zrezygnował. A contrario zatem, czego jednak TK w żaden sposób nie wysłowił w tym wyroku, Trybunał dostrzega wątpliwości w zakresie funkcjonowania tego przepisu. Skutkiem tego TK już po wydaniu wyroku

${ }^{28}$ Koper (2013): 7.

${ }^{29}$ Wyrok TK z 10 lipca 2019 r., K 3/16, OTK-A 2019/40, Dz. U. poz. 1378.

$30<$ https://www.rpo.gov.pl/sites/default/files/Wniosek\%20RPO\%20do\%20TK\%20ws. $\% 20$ tymczasowego\%20aresztowania.pdf> 
wydał postanowienie $\mathrm{e}^{31} \mathrm{w}$ trybie art. 35 ust. 1 ustawy z 30 listopada $2016 \mathrm{r}$. o organizacji i trybie postępowania przed Trybunałem Konstytucyjnym ${ }^{32}$, w którym zasygnalizował istnienie uchybień w prawie dotyczacych stosowania tymczasowego aresztowania ze względu na surowość kary grożącej oskarżonemu.

Trybunał podniósł, na co wskazywano powyżej, że „regulacje nakazujące uwzględnienie surowości kary grożącej oskarżonemu podczas stosowania tymczasowego aresztowania mają w Polsce długą tradycję i występowały (w różnych formach) nieprzerwanie od okresu międzywojennego [...]. Należy to odczytać jako wyraz trwałego przekonania ustawodawcy, że istnieje związek przyczynowo-skutkowy między przewidywanym wynikiem postępowania karnego a zachowaniem osoby, której postępowanie to dotyczy. Trybunał Konstytucyjny uznał, że opiera się ono na uprawnionym (zgodnym z zasadami doświadczenia życiowego) domniemaniu, że - co do zasady - im wyższa potencjalna kara grożąca oskarżonemu, tym większe jest prawdopodobieństwo, że będzie on podejmował próby bezprawnej ingerencji w tok postępowania". Choć TK uznaje istnienie przepisu art. 258 \$ 2 k.p.k. za konstytucyjnie uzasadnione, wskazuje jednocześnie, że na obawy związane z jego funkcjonowaniem, a mianowicie, że nie można wykluczyć, iż wysokość kary grożącej oskarżonemu będzie traktowana jako obiektywna okoliczność jednoznacznie wskazująca na potrzebę jego izolacji oraz że osłabia zasadę w myśl, której tymczasowe aresztowanie należy stosować jedynie w celu zabezpieczenia prawidłowego toku postępowania i do czasu, gdy jest to niezbędne, co może narażać ten przepis na niezgodność z zasadą konieczności ograniczenia wolności (art. 31 ust. 3 Konstytucji RP). W konsekwencji TK wskazuje na potrzebę takiego doprecyzowania treści tego przepisu, która wyeliminowałaby te wątpliwości przez powiązanie wysokości „grożącej oskarżonemu kary jako czynnik zwiększajacy prawdopodobieństwo utrudniania przez niego postępowanie (zwłaszcza na jego początkowym etapie), jednak niewystarczajaccy jako samodzielna podstawa zastosowania tymczasowego aresztowania w sytuacji braku realnych i konkretnych obaw podejmowania takich działań".

Podobne wskazanie zawarł TK w wyroku z 2012 r., wskazując, że: „Nie sposób bowiem nie zauważyć, że przesłanka stosowania tymczasowego aresztowania polegajacca na grożącej oskarżonemu surowej karze jest spełniona przez cały okres postępowania, w toku którego sąd ustala, czy oskarżony popełnił zarzucany mu czyn. Może ona ustać dopiero wtedy, gdy zmieniona zostaje kwalifikacja czynu, którego popełnienie zarzuca się oskarżonemu w ten sposób, że w świetle nowego zarzutu oskarżonemu będzie groziła kara niższa, niż wymaga tego art. $258 \S 2$ k.p.k." ${ }^{33}$.

31 Postanowienie TK z 17 lipca 2019 r., S 3/19, OTK-A 2019/41, Lex nr 2712693.

${ }^{32}$ Ustawa z 30 listopada 2016 r. o organizacji i trybie postępowania przed Trybunałem Konstytucyjnym, Dz. U. poz. 2072.

${ }^{33}$ Wyrok TK z 20 listopada 2012 r., SK 3/12, OTK-A 2012, nr 10, poz. 123, Lex nr 1227894. 


\section{Stanowisko Europejskiego Trybunału Praw Człowieka}

Omawiając funkcjonowanie przesłanki surowości grożącej oskarżonemu kary jako podstawy tymczasowego aresztowania, nie sposób pominać również stanowisko Europejskiego Trybunału Praw Człowieka w tej kwestii. W świetle jego orzecznictwa stosowanie izolacyjnych środków zapobiegawczych musi być konieczne i proporcjonalne, tzn. ich stosowanie nie może naruszać wolności człowieka w celu wymuszenia spełnienia obowiązku o mniejszym znaczeniu, a także stosowanie tego środka w czasie musi być podyktowane obiektywnymi potrzebami ${ }^{34}$.

Trybunał w Strasburgu jednolicie stoi na stanowisku, że „utrzymywanie się rozsądnego podejrzenia jest warunkiem sine qua non ważności przedłużenia pozbawienia wolności, lecz po upływie pewnego okresu przestaje wystarczać: Trybunał musi ustalić: (1) czy inne podstawy przedstawione przez organy sądowe nadal uzasadniaja pozbawienie wolności, oraz (2) gdy takie podstawy sa »istotne« i "wystarczajacce», czy krajowe organy władzy wykazały się "szczególną starannością" w prowadzeniu postępowania. Trybunał wskazywał także, iż uzasadnienie każdego okresu aresztowania, bez względu na to, jak krótkiego, musi zostać przekonująco wykazane przez władze. Przy podejmowaniu decyzji, czy osoba winna zostać zwolniona, czy pozbawiona wolności, władze są zobowiązane do zważenia alternatywnych środków zapewniających stawiennictwo tejże osoby na procesie"35. Wskazane zaś wyżej wątpliwości TK co do tego, że kwalifikacja prawna zarzucanego oskarżonemu czynu w zasadzie przez całe postępowanie może być samoistna podstawą tymczasowego aresztowania, są słuszne, albowiem w tym względzie ETPC prezentuje utrwaloną linię orzeczniczą (w tym również w skargach przeciwko Polsce), w myśl której „uzasadnione podejrzenie skarżonego o to, że dopuścił się on popełnienia poważnych przestępstw, mogło początkowo uzasadniać stosowanie wobec niego tymczasowego aresztowania. [...] Trybunał przyznaje, iż wobec powagi oskarżenia wniesionego przeciwko skarżącemu władze w uprawniony sposób mogły uznać istnienie takiego ryzyka" ${ }^{36}$. Trybunał wyraźnie też wskazuje: „mimo że surowość wyroku, który może zostać wymierzony oskarżonemu, jest istotnym elementem oceny ryzyka ucieczki lub powrotu do przestępstwa, potrzeba kontynuowania pozbawienia wolności nie może być oceniana jedynie z czysto abstrakcyjnego punktu widzenia, przy wzięciu pod uwage jedynie ciężaru przestępstwa" ${ }^{37}$.

W tym miejscu, w ramach krótkiego rysu prawnoporównawczego, zwrócić należy uwagę, iż podobne rozwiązanie w swojej regulacji tymczasowego aresztowania zawiera niemiecki k.p.k. (Strafprozeßordnung, StPO). O ile $§ 112$ StPO wymienia podstawowe przesłanki tego środka zapobiegawczego, wśród których wymienia m.in. ustalenie, że oskarżony uciekł lub ukrywa się oraz

\footnotetext{
34 Hofmański (2010): 170.

${ }^{35}$ Wyrok ETPC z 5 lipca 2016 r., 23755/07, Lex nr 2066267.

36 Wyrok ETPC z 18 października 2018 r., 15333/16, Lex nr 2594447; zob. też wyroki ETPC: z 19 lipca 2018 r., 52683/15, Lex nr 2592220; z 10 marca 2015 r. 34322/10, Lex nr 1652022.

37 Decyzja ETPC z 6 lutego 2018 r., Lex nr 2447257.
} 
podejrzenie matactwa, o tyle $\S 112$ a rozszerza ten katalog na „silne podejrzenie" (dringend verdächtig) w stosunku do szeregu przestępstw, wśród których niemiecki ustawodawca wymienia m.in. niektóre kategorie przestępstw seksualnych oraz stalking, a także w przypadku wielokrotnego lub powtarzającego popełniania przestępstw uszkodzenia ciała, kradzieży kwalifikowanej, rozboju. Wymagane jest ponadto istnienie ryzyka dalszego popełnienia tych przestępstw, a także prawdopodobieństwo wymierzenia oskarżonemu kary powyżej 1 roku pozbawienia wolności. W tym zatem przypadku podstawa tymczasowego aresztowania zbliżona jest do regulacji zawartej w art. $258 \S 3$ k.p.k. i realizuje przede wszystkim cel ochronny.

Inaczej jest jednak w przypadku przestępstw wymienionych w $§ 112$ ust. 3 StPO, tj. przestępstw przeciwko prawu międzynarodowemu, zabójstwa, ciężkiego uszczerbku na zdrowiu, ponieważ w takim przypadku istnieje możliwość tymczasowego aresztowania, nawet jeśli nie ma podstaw z $§ 112$ ust. 2 StPO. Rozwiązanie to jest w rzeczy samej analogicznym do regulacji polskiej, a różni się jedynie tym, że niemiecki kodeks posługuje się zamkniętym katalogiem przestępstw, co do których może znaleźć zastosowanie ten tryb tymczasowego aresztowania. Szeroki zakres stosowania tego przepisu próbował ograniczyć Federalny Trybunał Konstytucyjny, który orzekł, że w odniesieniu do przestępstw z katalogu $§ 112$ ust. 3 StPO musi zachodzić niebezpieczeństwo ucieczki lub bezprawnego utrudniania postępowania ${ }^{38}$. Powyższe wskazuje, że również niemiecki wymiar sprawiedliwości musiał dostosować literalne brzmienie przepisu do praktyki spełniającej wymóg strasburski.

\section{DALSZE PERSPEKTYWY}

W doktrynie zgodnie wskazywano, że funkcjonowanie surowości kary jako przesłanki aresztowej jest uzasadnione tym, że wynika z niej domniemanie utrudniania przez oskarżonego postępowania z uwagi na obiektywną obawę przed surowościa kary ${ }^{39}$. Jakkolwiek domniemanie to nie ma charakteru prawnego tylko faktycznego, ponieważ nie wynika z przepisu art. $258 \S 2$ k.p.k., to stwierdzić trzeba, że nie jest ono na tyle silne, ażeby stanowić samoistną podstawę w każdym przypadku do stosowania tymczasowego aresztowania. Dlatego, co podkreślano powyżej, na sądzie ciąży obowiązek wskazywania okoliczności sprawy, które powoduja, iż płynące z tego przepisu domniemanie faktyczne przeradza się w duży stopień prawdopodobieństwa podejmowania bezprawnych działań utrudniających postępowanie karne. Niezaprzeczalnie jednak istnienie wskazanej podstawy tymczasowego aresztowania jawi się jako konieczność.

\footnotetext{
38 Wiśniewski (2014): 401.

39 Stefański, Zabłocki (2019): 1003; Eichstaedt (2018): 959.
} 
$\mathrm{Z}$ drugiej jednak strony za stosowaniem tymczasowego aresztowania przemawiać mogą niektóre szczególne okoliczności sprawy, które nie będą uzasadniać prawdopodobieństwa utrudniania postępowania. Przykładowo, w razie popełnienia zbrodni, do której popełnienia oskarżony się przyznaje i nie zachodzi możliwość mataczenia w sprawie lub ukrycia dowodów ani ucieczki oskarżonego, konieczność tymczasowego aresztowania mająca na celu zabezpieczenie prawidłowego toku postępowania i zapewnienie sprawnego jego przebiegu wynikać będzie paradoksalnie z czynników pozaprocesowych. Ustawodawca polski zresztą dopuścił wprost możliwość oparcia tymczasowego aresztowania na przesłance pozaprocesowej $\mathrm{w}$ postaci zagrożenia popełnienia ponownego ciężkiego przestępstwa (art. $258 \S 3$ k.p.k.). Trafniej jednak powyższe ujmuje ustawodawca francuski, który w kodeksie postępowania karnego wskazał, że podstawę tymczasowego aresztowania stanowić może także potrzeba zapewnienia porządku publicznego zakłóconego popełnionym przestępstwem np. w celu uniknięcia samosądu ${ }^{40}$. Co do zasady powyższa okoliczność pozostaje poza obszarem zainteresowania wymiaru sprawiedliwości, co rodzi pytanie, czy tak być powinno.

W przytoczonym wyżej postanowieniu sygnalizacyjnym TK odniósł się jedynie do tego, że istnieje społeczne przekonanie co do tego, że surowość grożącej oskarżonemu kary skutkować będzie jego skłonnością do utrudniania postępowania. Prawdziwe jest jednak też stwierdzenie, że społeczne poczucie sprawiedliwości, jak również poczucie zagrożenia skutkują tym, że opinia społeczna oczekuje izolacji sprawcy przestępstwa o gatunkowo ciężkim charakterze na czas trwania postępowania. Oczywiste jest, że wymiar sprawiedliwości nie może być sprawowany populistycznie, niemniej Rzeczpospolita Polska jako demokratyczne państwo prawne winna zorganizować postępowanie karne w ten sposób, aby realizować nie tylko prawa oskarżonego, lecz także czynić zadość postulatom ochrony społeczeństwa. Dlatego też w doktrynie procesu karnego wyróżnia się funkcje pozaprocesowe tymczasowego aresztowania, wskazując na ochronę osoby oskarżonego oraz zaspokojenie oczekiwań społecznych ${ }^{41}$. W pełni podzielić należy wskazanie Barbary Nity i Wojciech Hermelińskiego, że: „Sąd orzekający w kwestii tymczasowego aresztowania powinien zatem precyzyjnie określać interes publiczny, którego wystapienie jest konieczne, aby zgodnie z Europejska Konwencją Praw Człowieka, przy uwzględnieniu zasady domniemania niewinności, izolacyjny środek zapobiegawczy mógł być zastosowany lub przedłużony" ${ }^{42}$. Powyższe jest szczególnie istotne wraz z upływem trwania postępowania, ponieważ jak wskazywano wcześniej - wraz z czasem maleje zagrożenie wynikające z surowości kary. W tym też celu stosowaniu środków zapobiegawczych powinno towarzyszyć sprawne postępowanie zarówno na etapie postępowania przygotowawczego, jak i jurysdykcyjnego, tak aby tymczasowa $z$ natury izo-

\footnotetext{
${ }^{40}$ Głębocka (2014): 260.

41 Dąbkiewicz (2012): 53.

42 Hermeliński, Nita-Światłowska (2018): 15.
} 
lacja sprawcy nie spowodowała, iż orzeczony następnie wyrok stałby się bezprzedmiotowy.

O ile jednoznacznie negatywnie należy oceniać stosowanie tymczasowego aresztowania w kategoriach represyjnych, o tyle nie można tego samego powiedzieć o jego społecznej funkcji, z takim jednak uzupełnieniem, że obok zagrożenia utrudnienia postępowania ustawodawca powinien rozważyć wpisanie do tego przepisu klauzuli generalnej ochrony porządku publicznego, istota której jest upoważnienie organu procesowego „do oparcia podejmowanej decyzji na kryteriach pozaprawnych" ${ }^{43}$ i jako taka nie może być postrzegana jako niedookreśloność prawa, ponieważ odsyła do katalogu wartości pozaprawnych ${ }^{44}$. Nie ma też przeszkód ku temu, aby stanowiła ona podstawę rozstrzygania kolizji w przypadku ochrony prawa do wolności. Nie byłby w takim układzie słuszny zarzut nieokreśloności podstawy stosowania izolacyjnego środka zapobiegawczego, ponieważ jego stosowanie byłoby ograniczone jedynie do zbrodni i tych występków, których górna granica zagrożenia wynosi przynajmniej 8 lat. Za każdym razem sąd stosujący ten środek winien wykazać duży stopień prawdopodobieństwa zagrożenia dla porządku publicznego i sposób jego rozumienia w danej sprawie. Tak uregulowana przesłanka aresztowa odnosząca się do kryteriów pozaprocesowych, które jednak w postanowieniu o zastosowaniu środka powinna być skonkretyzowane, wydaje się trafniejszym sposobem ujęcia tej przesłanki aniżeli obecne jej powiązanie $\mathrm{z}$ domniemaniem podejmowania czynności utrudniających postępowanie.

\section{ZAKOŃCZENIE}

Podsumowując powyższe rozważania, opowiedzieć należy się za tym, iż w polskiej regulacji dotyczacej izolacyjnego środka zapobiegawczego potrzebny jest przepis stanowiący pozaprocesowa podstawę aresztowania, który pełnić winien funkcję ochronna. De lege lata funkcję tę spełniaja przepis art. $258 \S 3$ k.p.k. oraz art. $258 \S 2$ k.p.k. O ile w tym pierwszym przypadku konieczność stosowania tymczasowego aresztowania nie budzi wątpliwości, o tyle w przypadku zagrożenia kara jako podstawy tymczasowego aresztowania podzielić należy wątpliwości wskazujące na „ułomność” tego przepisu. Jakkolwiek jest to podstawa potrzebna wśród szczególnych przesłanek tymczasowego aresztowania, to jej sformułowanie rodzi niebezpieczeństwo zaistnienia automatyzmu pomiędzy surową kwalifikacją prawną zarzucanego czynu a zastosowaniem tego środka zapobiegawczego. W tym celu, w ślad za stanowiskiem Trybunału Konstytucyjnego, pożądane jest

\footnotetext{
${ }^{43}$ Skorupka (2013): 247.

${ }^{44}$ Wyrok TK z 17 października 2000 r., SK 5/99, OTK 2000, nr 7, poz. 254, Lex nr 44558.
} 
dokonanie takiej zmiany przez ustawodawcę omawianego przepisu, która wyeliminowałaby ów automatyzm i nieweryfikowalne domniemanie faktyczne na rzecz powiązania kwalifikacji prawnej z obowiązkiem wykazania, że tymczasowe aresztowanie ma chronić porządek publiczny i zapewnić sprawność postępowania.

Jan Kluza

Uniwersytet Jagielloński

jan.kluza@doctoral.uj.edu.pl

https://orcid.org/0000-0002-0929-6093

Dąbkiewicz, K. (2012). Tymczasowe aresztowanie.

Eichstaedt, K. (2016). Komentarz do art. 258 k.p.k., [w:] D. Świecki (red.) (2016). Kodeks postępowania karnego. Komentarz do zmian 2016. Warszawa: 248-254.

Eichstaedt, K. (2018). Komentarz do art. 258 k.p.k., [w:] D. Świecki (red.) (2017). Kodeks postępowania karnego. Komentarz. Tom 1. Warszawa: 949-962.

Głębocka, J. (2014). Francuska procedura karna, [w:] P. Kruszyński (red.) (2014). Proces karny. Rozwiązania modelowe w ujęciu prawnoporównawczym. Warszawa: 259-268.

Grzęda, E. (2015). Przesłanka tymczasowego aresztowania z art. 258 § k.p.k. Uwagi na marginesie uchwały Sądu Najwyższego z 19 stycznia 2012 r. (I KZP 18/11) oraz nowelizacji Kodeksu postępowania karnego. Czasopismo Prawa Karnego i Nauk Penalnych 19(3): 137-166.

Hermeliński, W., Nita-Światłowska, B. (2018). Tymczasowe aresztowanie ze względu na grożąca oskarżonemu karę. Palestra 6: 14-25.

Hofmański, P. (2010). Komentarz do art. 5 Europejskiej Konwencji Praw Człowieka, [w:] L. Gardocki (red.) (2010). Konwencja o ochronie praw człowieka i podstawowych wolności. Komentarz do artykułów 1-18. Tom 1. Warszawa: 154-241.

Hofmański, P. (red.) (2011). Kodeks postępowania karnego. Tom 1: Komentarz do artykułów 1-296. Warszawa.

Hofmański P., Waltoś, S. (2016). Proces karny. Zarys systemu. Warszawa.

Koper, R. (2013). Podstawy i terminy tymczasowego aresztowania w świetle Konstytucji. Państwo i Prawo 69(5): 3-16.

Murzynowski, A. (1997a). Refleksje na temat zmian w przepisach dotyczących stosowania tymczasowego aresztowania. Prokuratura i Prawo 1: 7-25.

Murzynowski, A. (1997b). Wątpliwości w kwestii stosowania tymczasowego aresztowania. Prokuratura i Prawo 1: 137-140.

Nita. B., Światłowski, A. (2013). Podstawa dowodowa tymczasowego aresztowania. Państwo i Prawo 68(2): 87-101.

Peiper, L. (1932). Komentarz do kodeksu postępowania karnego i do przepisów wprowadzających tenże kodeks. Kraków.

Różycki, S. (1933). Kodeks postępowania karnego: komentarz oparty na tle motywów ustawodawczych oraz orzecznictwa Sądu Najwyższego. Nowogródek.

Skorupka, J. (2012). Limitacja tymczasowego aresztowania w polskim procesie karny. Państwo i Prawo 67(3): 55-64.

Skorupka, J. (2013). O sprawiedliwości procesu karnego. Warszawa.

Stefański, R. (1998). Komentarz do art. 258 k.p.k., [w:] J. Bartoszewski et al., Kodeks postępowania karnego. Komentarz. Tom 1. Warszawa. (Lex/el.).

Stefański, R., Zabłocki, S. (red.) (2019). Kodeks postępowania karnego. Tom 2: Komentarz do art. 167-296. Warszawa.

Wiśniewski, Ł. (2014). Niemiecki proces karny, [w:] P. Kruszyński (red.), System prawa karnego procesowego. Tom 2: Proces karny. Rozwiązania modelowe w ujęciu prawnoporównawczym. Warszawa: 396-402. 


\section{ON THE NEED FOR SEVERE PENALTIES \\ AS AN INDEPENDENT REASON FOR APPLYING PRE-TRIAL DETENTION: \\ CONSIDERATIONS AND CONCLUSIONS REGARDING THE INTERPRETATION OF ARTICLE 258 PARA. 2 OF THE CODE OF CRIMINAL PROCEDURE}

Sum mary

Article $258 \S 2$ of the Code of Criminal Procedure stipulates that pre-trial detention may be applied if the accused person is charged with a felony or offense with an upper threat limit of at least 8 years. This provision raised a number of controversies as to whether it could constitute an independent basis for the use of pre-trial detention without the existence of other specific conditions for the use of this measure, which led to the Supreme Court adopting a resolution in which it stated that this provision could be an independent basis for the use of pre-trial detention. However, this did not eliminate doubts about this provision, which in turn led to to review of its compliance with the Constitution. Contrary to numerous criticisms of this provision, The author's position is that its functioning is justified; however, it is correct to indicate that it requires the intervention of the legislator, which would force the court adjudicating on the application for detention on remand to indicate in concreto the factors justifying the use of this measure.

Keywords: pre-trial detention; protective function; preventive measures; threat of punishment; public order 